\title{
Prevalence of Subclinical Mastitis in some Dairy Cattle Farms in Kuwait
}

\author{
AbdelKhalek $\mathrm{A}^{1}$; El-sherbini $\mathrm{M}^{1}$; and Alanzi S. $\mathrm{J}^{1}$ \\ ${ }^{1}$ Food Hygiene and Control Department, Faculty of Veterinary Medicine, Mansoura University, Mansoura
}

\section{ABSTRACT}

\begin{abstract}
A survey to prevalence of subclincal mastitis (SCM) in some dairy cattle farms in state of Kuwait was carried out. 200 quarter milk samples from apparently healthy dairy cows. 200 quarter milk samples from apparently healthy dairy cows at Kuwait were investigated for subclinical mastitis using California mastitis test (CMT), Somatic cell count (SCC) and bacteriological isolation. The results revealed that the prevalence of subclinical mastitis was $45 \%$ and bacterial culture was positive in $37.5 \%$ SCC was assessed in 200 milk samples, the minimum and maximum SCC was $0.12 \times 105$ cell/ $\mathrm{ml}$ and $4.75 \times 105$ cell/ ml with the mean of $1.7 \pm 18.11 \times 105$ cell/ $\mathrm{ml}$. The cultural examinations to determine subclinical mastitis causative agents revealed that the isolated bacterial strains in examined milk samples of cows were Staphyloccocus aureus, Streptococcus agalactia, E. coli and Pseudomanas aeruginosa with distribution of $37.6 \%, 20.5 \%, 19.4 \%$ and $3.2 \%$, respectively as single infection from total 93 isolated bacterial strains. Meantime, there were mixed infection of (Staphyloccocus aureus + E. coli); (Streptococcus agalactia + E. coli) and (Staphyloccocus aureus + Pseudomanas aeruginosa) with the recovery rates of distribution of $8.6 \%, 9.7 \%$, and $1 \%$, respectively. Antibiogram profile of some representative field strains of Staphyloccocus aureus, Streptococcus agalactia, E. col and Pseudomanas aeruginosa isolated from subclinical mastitis cases to 11 different antibiotics. It revealed that all Staphyloccocus aureus, Streptococcus agalactia E. coli and Pseudomanas aeruginosa isolates were highly sensitive to enrofloxacillin, and Cloxacillin. However, it showed variable sensitivity degrees to other tested antibiotics. It could be concluded that subclinical mastitis constitutes a major economic and healthy problem for dairy herd in Kuwait.
\end{abstract}

Keywords: Subclinical mastitis, dairy cattle, Kuwait, bacterial causes, antibiogram.

\section{INTRODUCTION}

Milk is an important diet of human beings. It contains a wide range of dietary constituents of vital importance like water, proteins, lactose, minerals and vitamins (Allore, 1993). Subclinical mastitis (SCM) is an economically important disease of dairy cows and has ranks amongst the factors that limit milk production. It has a tendency to persist because usually it remains unobserved which results in high milk somatic cell count (SCC) and reduced milk production, treatment cost and development of clinical mastitis which leads to heavy economical losses (Leitner et al., 2011). Total milk loss from quarters affected with subclinical mastitis has been estimated to vary from $10 \%$ to $26 \%$ and approximately $75 \%$ of the economic loss from subclinical mastitis is attributable to loss of milk production (Radostits et al., (2000). Milk from the affected cows that contaminated with bacteria makes it unhealthy for human consumption and has a zoonotic importance (Sharif et al. (2009).
Subclinical mastitis is a great challenge among the dairy farmers as it is indirect and more difficult to detect due to the absence of any visible symptoms and needs the availability of a rapid screening test for the early detection of the disease (Viguier et al., 2009). It is characterized by reduced host defense mechanism (Owen et al., 2000), as well as alterations in some enzymes and metabolites (El- Zubeir et al., 2005; Andrei et al., 2009 and Matei et al., 2010).

The most significant subclinical abnormality of the milk is the increase in somatic cell counts, the most common measure of milk quality and udder health (Radostits et al., 2000). Milk and other dairy products that obtained from the subclinical mastitis cases are commonly contaminated with Staphylococcus aureus and Streptococcus agalactiae (Hameed et al. (2006). Milk from cows with subclinical mastitis accidentally mixed into bulk milk enters food chain and poses a hazard to human health. 
Contagious mastitis pathogens are generally spread from cow-to-cow with the infected udder being the primary source of the pathogen, via milk-contaminated fomites at milking, milkers and by milking machine (Awandkar et al., 2009), while environmental mastitis pathogens are found in the environment where the cow lives and spread directly from there to the udder and transmitted by contact of teats with contaminated soil, bedding and water with fecal materials (Mekonnen and Tesfaye, 2010).

Various methods of detection of subclinical mastitis have been found including California Mastitis Test (CMT) which is considered a better and a rapid indirect diagnostic tool to detect subclinical mastitis (Zaki et al., 2008). Also, measurement of somatic cell count and detection of the causative microorganisms (Viguier et al., 2009). As well as bacteriological culture of milk samples served as a gold standard method for assessment of different tests used for diagnosis of subclinical mastitis and evaluation of intramammary infection (National Mastitis council, 1999). Antibiogram assessment of isolated bacteria is necessary tool for treatment and tracing the emergence of muti-drug resistance strain of such isolated bacteria. Many authors evaluated the sensitivity of isolated bacteria from subclinical mastitis against different antibiotics (Denamiel et al., 2005; Idriss et al., 2014 and Singh et al., 2018).

Due to the economic and public health importance of subclinical mastitis, the aim of this work was to determine prevalence of subclinical mastitis and associated causative bacteria, the association of SCC and occurrence of bacteria with SCM in Kuwait dairy farms was evaluated. Also, antibiogram assessment of isolated bacteria was performed.

\section{MATERIALS AND METHODS}

\subsection{Milk sampling:}

200 quarter milk samples were collected from each quarter of 200 randomly selected apparently healthy lactating cows were collected from different dairy farms in state of Kuwait for detection of subclinical mastitis during the period from April till the end of September 2017. Samples transferred to the laboratory in ice-box to maintain its chemical and microbiological status unchangeable (Radostits et al., 2007). All animals had no evidence of apparently healthy at the time of sampling. Each sample was mixed thoroughly before being divided into two parts. The first was screening by CMT and SCC, and the second for bacteriological examinations.

\subsection{Detection of subclinical mastitis:}

200 quarter milk samples were tested for subclinically mastitic cows by screening California mastitis test according to Schalm and Noorlander (1957).

\subsection{Somatic cell count:}

Collected quarter milk samples were examined for SCC according to Zecconi et al. (2002). By using automatically Bently Soma count, 150 (Bentley U.S.A). The sample was warmed in water bath at $40^{\circ} \mathrm{C}$ for 5 minutes then mixed automatically before automatic reading of SCC by Bently Soma count 150 (Bentley U.S.A.) for dispersion of fat globules. The somatic cell count measures the number of white blood cells including neutrophils, macrophages, lymphocytes, eosinophils and various epithelial cell types of the mammary gland in milk that were present in large number in case of subclinical mastitis.

\subsection{Bacteriological examination of milk samples:}

\subsubsection{Preparation and cultivation of milk samples:}

Fresh milk samples were incubated aerobically at $37^{\circ} \mathrm{C}$ for 24-48 h., then loopfulls of incubated milk were streaked onto plates of blood agar (for detection of hemolysis), Mannitol salt agar (selective media for Staphylococci), Edward's media (selective media for Streptococci) and Eosine Methylene blue (EMB) agar (selective media for E. coli).Pseudomanas selective agar( selective media for Pseudomanas aeruginosa).The suspected colonies were further identification according to Quinn et al. (2002) and Collee et al. (1989).

\subsubsection{Antibiogram assessment of isolated bacterial strains from subclinical mastitic milk:}

Antibiogram profile of some representative field strains of Staphyloccocus aureus (25), Streptococcus agalactia (15), E. coli (15), with E. coli and Pseudomanas aeruginosa (3) isolated from subclinical mastitiscases isolated from mastitic cows are purified and identified biochemically and tested in vitro for theirsensitivities to 11

different types of antibiotics and commonly used in veterinary practical field for mastitis prevention and control were used in the present work which including; Penicilling $(10 \mu \mathrm{g})$, gentamycin $(10 \mu \mathrm{g})$, enrofloxacilli $\mathrm{n}(10 \mu \mathrm{g})$,Cloxacillin $(30 \mu \mathrm{g})$, Streptomycin $(10 \mu \mathrm{g})$, colistin $(25 \mu$ $\mathrm{g})$, neomycin $(30 \mu \mathrm{g})$, erythromycin $(15 \mu \mathrm{g})$, kanamycin $(30 \mu \mathrm{g})$, amoxycillin $(30 \mu \mathrm{g})$ and ampicillin $(30 \mu \mathrm{g})$.using standard proc edures as described by Quinn et al. (1994).

\section{RESULTS AND DISCUSSION}

Subclinical mastitis is a disease in which there is no detectable inflammatory change in the udder and no 
observable abnormalities in the milk. However, there are many cellular, biochemicals, immunological and enzymatic changes are present in milk from udder with subclinical infection. These changes are detected by laboratory tests such as screening and routine tests applied for diagnosis of subclinical mastitic cases. Subclinical mastitis is more prevalent than the clinical form, so, it causes great losses in the dairy herds (Joshi and Gokhale, 2004). Also, subclinical mastitis usually develops the clinical form, it reduces milk production and adversely affect milk quality. Total milk loss from quarters affected with subclinical mastitis has been estimated to vary from $10 \%$ to $26 \%$. Approximately $75 \%$ of the economic loss from Subclinical mastitis is attributable to loss of milk production. The most significant subclinical abnormality of the milk is the increase in somatic cell count, which is the most common laboratory way of milk quality and udder health (Sharif et al. (2009).

Table (1): Results of SCM and bacteriological culture in mastitic cow

\begin{tabular}{|c|c|c|c|}
\hline \multirow[b]{2}{*}{ Parameters } & \multirow{2}{*}{$\begin{array}{l}\text { No. of } \\
\text { Quarters } \\
\text { samples }\end{array}$} & \multicolumn{2}{|c|}{ Positive samples } \\
\hline & & No. & $\%$ \\
\hline $\begin{array}{l}\text { SCM positive }(\mathrm{SCC}>=1 \mathrm{x} \\
10^{5} \text { cells } / \mathrm{ml}\end{array}$ & \multirow{2}{*}{200} & 90 & 45 \\
\hline Bacteriological culture & & 75 & 37.5 \\
\hline
\end{tabular}

Results summarized in Table (1) showed that by the investigating a total of 200 cow's quarter milk samples using California mastitis test and bacteriological isolation revealed that with prevalence of subclinical mastitis was $45 \%$ (90 out of 200 ) and bacterial culture was positive in $37.5 \%$ (75 were positive out 200) Nearly similar findings were previously reported by many authors (Bitew et al., 2010; Girma, 2010 and Mir et al., 2014) who reported prevalence of 32.4, 34.4 and $30.73 \%$, respectively. However, higher prevalence was cited by many investigators (Zeryehun et al., 2013; Abrahmsen et al., 2014 and Zenebe et al., 2014). On the other hand lower prevalence was previously reported by many workers (Biffa et al., 2005; Alemu et al., 2013 and Zizet, 2015).

In the present study, the somatic cell count was assessed in 200 milk samples. As shown in table (2), the minimum and maximum SCC was $0.12 \times 10^{5}$ cell/ ml and $4.75 \times 10^{5}$ cell $/ \mathrm{ml}$ with the mean of $1.7 \pm 18.11 \times 10^{5} \mathrm{cell} / \mathrm{ml}$. Milk SCC has been extensively as indicators of intramammary infection (IMI), Somatic cell count has been included as a component of the definition of mastitis and the original limit for SCC of a healthy quarter is $500.000 \mathrm{cell} / \mathrm{ml}$. The definition

Table (1): Prevalence of Subclinical mastitis and status of quarters analyzed Bacteriologically Parameter.
Was a guide for diagnosis, even though $50 \%$ of truly infected quarters could at any time have a cell count less than the break-point of $500.000 \mathrm{cell} / \mathrm{ml}$ (International Dairy Federation (IDF: 1971). SCC is a useful index for detection of subclinical mastitis and milk quality. The SCC of normal milk is less than 200.000 cells $/ \mathrm{ml}$, higher SCC is considered as abnormality in milk and indicates udder infections. High SCC causes a rise in whey protein and a decrease in casein, resulting in a considerably lower cheese yields. Shorter shelf life and adverse milk flavor are other consequences of high SCC (Bilal and Ahmed, 2004)

Table (2): Mean SCC of subclinical mastitic mammary quarters

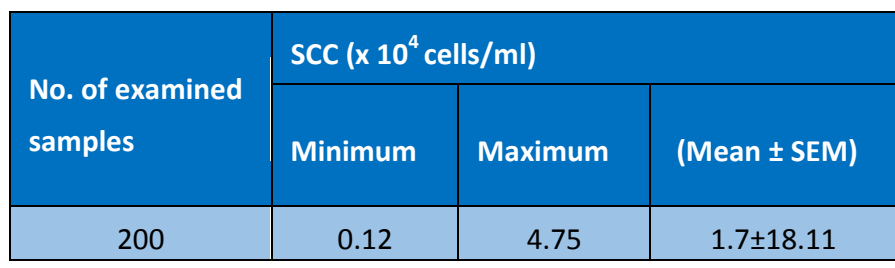

Results summarized in Table (3) showed that frequency distribution of bacteriological isolates recovered from subclinical mastitiic milk of 200 samples of dairy cows at quarter level in state of Kuwait. The cultural examinations to determine subclinical mastitis causative agents revealed that the isolated bacterial strains in examined (200) milk samples of cows were Staphyloccocus aureus, Streptococcus agalactia, E. coli and Pseudomanas aeruginosa with distribution of $37.6 \%, 20.5 \%, 19.4 \%$ and $3.2 \%$, respectively as single infection from total 93 isolated bacterial strains. Meantime the results proved that there were mixed infection of (Staphyloccocus aureus + E. coli); (Streptococcus agalactia + E. coli) and (Staphyloccocus aureus + Pseudomanas aeruginosa) with the recovery rates of distribution of $8.6 \%, 9.7 \%$, and $1 \%$, respectively as mixed infection from total 93 isolated bacterial strains. These bacterial infections were previously isolated by Shereen (2014). The results of the present study concluded that Staphyloccocus aureus was the most prevalent isolate. Similar incidence of staphylococci in cows was reported by Mir et al. (2014). A lower incidence of Staphyloccocus species in cows was reported by Hanan et al (2015). Moreover, a higher percentage $(77.2 \%)$ and $(63.6 \%)$ of Staphyloccocus species in cows was reported by Mekibib et al. (2010) and Elbably et al. (2013).

The high incidence of Staphyloccocus aureus in case of subclinical mastitis may due to the wide spread use of antibiotics especially dipping teats in sanitizers (Jones and Swisher, 1998). The obtained results clarified that the high incidence of Streptococcus agalactia in cases of subclinical mastitis was due to the increase in the infection rates by Streptococcus species. This finding was fully supported by Kumar et al. (2014). 
In the present study, E. coli prevalence as a causative agent of mastitis was $19.4 \%$. Similar incidence $(18.7 \%)$. of $E$. coli in cows was reported by Elbably et al. (2013). However, a lower result $(4.6 \%)$ of $E$. coli in milk of cows was previously reported by Mekibib et al. (2010). Furthermore, a higher incidence (46.32) of $E$. Coli in cows were reported by Hamdy (2009). E. coli is a frequent cause of bovine mastitis and widely distributed in nature emphasized that $E$. coli serotypes in mastitis milk were similar to fecal isolates. The incidence of $E$. coli mastitis in the present study may be attributed to many risk factors associated with housing, such as dietary changes or may be due to the heavy contamination of bedding and poor hygienic measures which cause a consequent udder infection from fecal contamination on the bedding (Robertson et al,. 1994). From the results achieved in Table (3), one could be noticed the most mixed infection was Staphyloccocus aureus with $E$. coli followed by Streptococcus agalactia with $E$. coli. These data were in agreement of results of Dalia (2015).

Table (3): Frequency distribution of isolates from subclinical mastitis.

In the present study the frequency distribution of isolates and mean SCC of subclinical mastitic quarters according to the types of bacteria causing SCM in dairy cows was determined. The results achieved in Table (4) proved that there are a correlation between the infection of quarter and type of isolated bacteria such as single infection with Pseudomanas aeruginosa and Streptococcus agalactia, the mean SCC \pm SEM were $3.8 \pm 0.96 \times 10^{5}$ and $2.8 \pm 1.09 \times 10^{5}$, followed single infection with $E$. coli and Staphyloccocus aureus, the mean SCC \pm SEM were $2.2 \pm 1.2 \times 10^{5}$ and $1.33 \pm 0.97 \times 10^{5}$. However; in mixed infection with Streptococcus agalactia and E. coli, the mean SCC \pm SEM were highest one $\left(4.2 \pm 1.7 \times 10^{5}\right)$. However, mixed infection of Staphyloccocus aureus with Pseudomanas aeruginosa, the mean SCC \pm SEM were $1.8 \pm 0.33 \times 10^{5}$. The last one of mixed infection of Staphyloccocus aureus with E. coli, the mean SCC \pm SEM were $1.1 \pm 0.33 \times 10^{4}$. It proved that Pseudomanas aeruginosa is organism must be not ignored as causative of subclincal mastitis. Moreover, the significant role of mixed infection of Streptococcus agalactia and E. coli the most potential organisms as causative of subclinical mastitis and of economic impact with public health significance as a cause of many neonatal infection and digestive and urogenital disorders in human consumers of such suclinically mastitic milk. This correlation to the type of bacterial isolates from the examined subclinical milk samples of cows come in agreement with the results of Bytyqi et al. (2010) who found that the environmental organisms produced less SCC than highly contagious ones. The result in Table (4) concluded that the mixed bacterial infections of subclinical mastitis showed higher SCC, This conviction was fully supported by the results of Zeinhom et al. (2013) who reported the mixed bacterial infections in dairy cows had higher level of SCC than single infections. It could be noticed from the results achieved in Tables (1 to 4), that subclinical mastitis was more prevalent in examined cows in Kuwait. CMT and SCC are good laboratory tests for evaluation of subclinical mastitis in cows.

Antibiogram profile of some representative field strains of Staphyloccocus aureus (25), Streptococcus agalactia (15), E. coli (15), with E. coli and Pseudomanas aeruginosa (3) isolated from subclinical mastitis cases to 11 different antibiotics commonly used in mastitis prevention and control were used the present work including; Penicillin $\mathrm{G}(10 \mu \mathrm{g})$, gentamycin $(10 \mu \mathrm{g})$, enrofloxacillin $(10 \mu \mathrm{g})$, Cloxacillin

$(30 \mu \mathrm{g})$, Streptomycin $(10 \mu \mathrm{g})$, colistin $(25 \mu \mathrm{g}), \quad$ neomycin $(30 \mu$ g), erythromycin $(15 \mu \mathrm{g})$, kanamycin

$(30 \mu \mathrm{g})$, amoxycillin $(30 \mu \mathrm{g})$ and ampicillin $(30 \mu \mathrm{g})$. The results in Table (5), revealed that all Staphyloccocus aureus isolates (25) were highly sensitive to enrofloxacillin, Cloxacillin and kanamycin, however, it showed sensitive to gentamycin

\begin{tabular}{|c|c|c|c|}
\hline & Bacterial isolates & $\begin{array}{l}\text { Cows a } \\
\text { level } \\
\text { No. }\end{array}$ & $\begin{array}{l}\text { arter } \\
(\%)\end{array}$ \\
\hline Single & Staphylococcus aureus & 35 & 37.6 \\
\hline \multirow[t]{3}{*}{ isolates } & Streptococcus agalactia & 19 & 20.5 \\
\hline & E.coli & 18 & 19.4 \\
\hline & Pseudomonas aeruginosa. & 3 & 3.2 \\
\hline Mixed & Staphaureus+ E.coli & 8 & 8.6 \\
\hline \multirow[t]{2}{*}{ isolates } & Streptagalactia+E.coli & 9 & 9.7 \\
\hline & $\begin{array}{l}\text { Staph. aureustPs. } \\
\text { aeruginosa }\end{array}$ & 1 & 1 \\
\hline Total & & 93 & 100 \\
\hline
\end{tabular}

and neomycin. Moreover, it was intermediate to Streptomycin. On the other hand all Staphyloccocus aureus isolates were resistant to penicillin-G, ampicillin, colistin, erythromycin and amoxicillin. Table (5) also proved that all Streptococcus agalactia (15) were highly sensitive to enrofloxacillin, Cloxacillin and gentamycin, however, it showed sensitive to neomycin. Moreover, it was intermediate to kanamycin and Streptomycin. On the other hand all Streptococcus agalactia isolates were resistant to penicillin-G, ampicillin, colistin, erythromycin and amoxicillin. Moreover, Table (5) also proved that all E. coli (15), were highly sensitive to enrofloxacillin, however, it showed sensitive to Cloxacillin, kanamycin, penicillin-G, and ampicillin, erythromycin and Streptomycin. Moreover, it was intermediate to gentamycin, and neomycin. On the other hand all $E$. coli isolates were resistant to colistin and amoxicillin. Furthermore, the results in table (5) clarified that all Pseudomanas aeruginosa isolates (3) were highly sensitive to enrofloxacillin, and gentamycin however, it showed sensitive to Cloxacillin, kanamycin, erythromycin and Streptomycin Moreover, it was intermediate to penicillin-G, ampicillin and neomycin. On the other hand all Pseudomanas aeruginosa isolates were resistant to colistin, and amoxicillin. 
Table 4. Frequency distribution of isolates and mean SCC of subclinical mastitic quarters according to the types of bacteria causing SCM in dairy cows Bacterial isolates

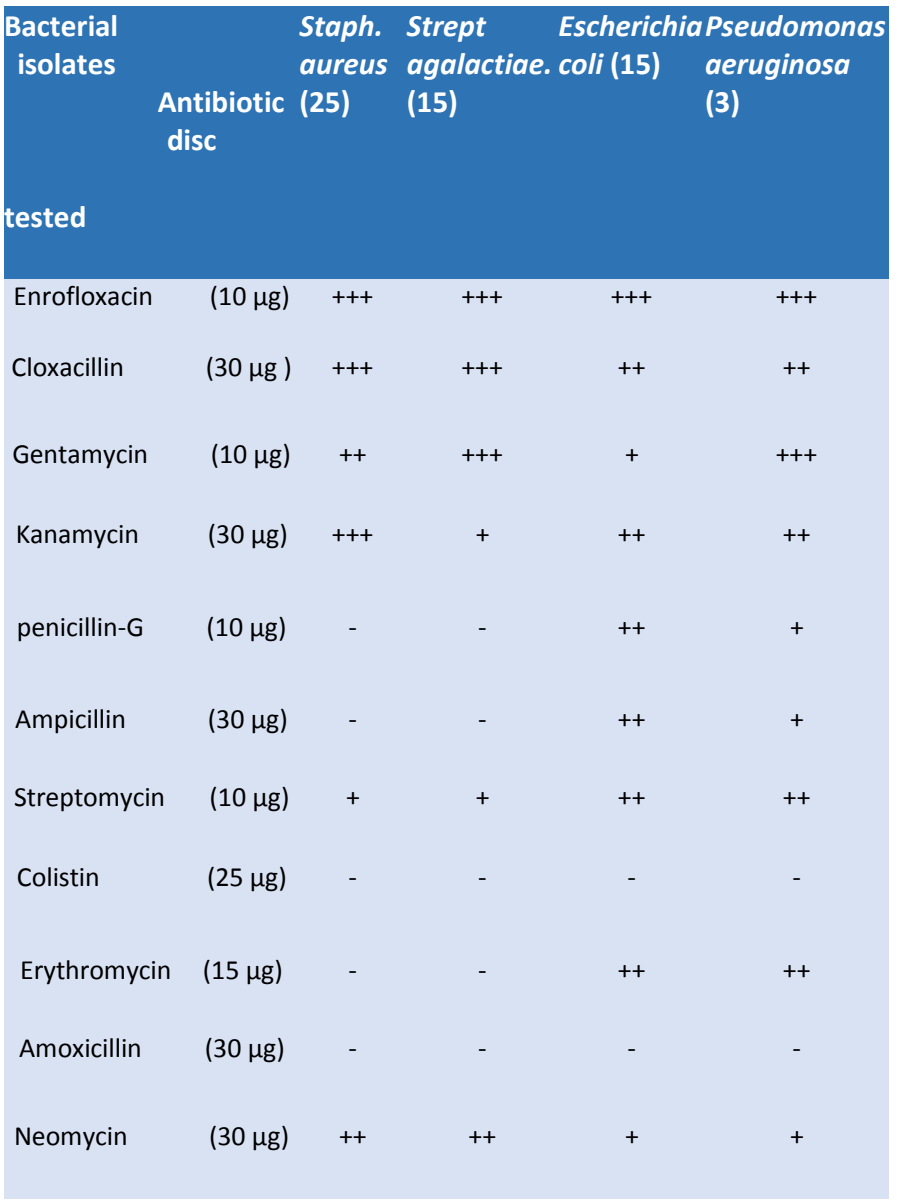

The present study were coincided the results of many investigators and researchers as Bhattacharya et al. (2002) found that most of stapylococc al and

streptococcal isolates from cows suffering from clinical and su bclinical mastitiswere highly sensitive to ciprofloxacin, tetracyc line and gentamycin, less susceptible to penicillin, ampicillin an d cloxacillin. Denamiel et al. (2005) found streptococcal strains, Strept. agalactiae and Strept. dysgalactiae strains isolat edfrom bovine intramammary infections in Argentina were resistance to erythromycin and clindamycin but no isolates were resistance to penicillin G. Suriyasathaporn (2011) found that

S. aureus, S.dysgalactiae and CNS were susceptible to most e xamined antibiotics. The present result also agrees with Idriss et al. (2014) who found most of the isolated pathogens were sensitive to enrofloxacin. Furthermore, Singh et al. (2018) reported that antibiogram for Streptococcus agalactiae revealed the highest sensitivity to ofloxacin, ciprofloxacin, gentamicin and resistance to amoxicillin and doxycycline; Staphylococcus aureus isolates were showed the highest sensitivity to ciprofloxacin, doxycycline, azithromycin and sparfloxacin and resistance to amoxycillin and gentamicin. Similarly, E. coli revealed the highest sensitivity to

\begin{tabular}{|c|c|c|}
\hline Bacterial isolates & No. of quarter & $\begin{array}{l}\text { SCC }\left(\times 10^{5} \text { cells } / \mathrm{ml}\right) \\
\text { (Mean } \pm \text { SEM) }\end{array}$ \\
\hline Staphylococcus aureus & 35 & $1.33 \pm 0.97$ \\
\hline Strept. Agalactiae & 19 & $2.8 \pm 1.09$ \\
\hline Escherichia coli. & 18 & $2.2 \pm 1.2$ \\
\hline Pseudomonas aeruginosa & 3 & $3.8 \pm .96$ \\
\hline $\begin{array}{l}\text { Staphylococcus aureust } \\
\text { E. coli }\end{array}$ & 8 & $1.1 \pm .33$ \\
\hline Strept. agalactiae + E.coli & 9 & $4.2 \pm 1.7$ \\
\hline $\begin{array}{l}\text { Staph.aureus + Ps. } \\
\text { aeruginosa }\end{array}$ & 1 & $1.8 \pm .33$ \\
\hline
\end{tabular}

Table (5): Antibiotic sensitivities of bacterial isolates from mastitic co ws.

$(+++)$ : Highly Sensitive; (++): Sensitive; (+): Intermediate; (-): Resistant Conclusion

In conclusion, our study suggested that using MOS as prebiotic; potentially improved growth performance parameters, survival rates; besides the improvement of gut morphology and microbiota that could be beneficial to fish health. Taken together these results, we conclude that however, treatment with the prebiotic, MOS, in feed and water, could be used to enhance the measured parameters of tilapia, using MOS as dietary additives will be more applicable and economic in feed than in both water and feed.

\section{Conflict of interest}

Authors declare that they have no conflict of interest

\section{REFERENCES}

Abrahmsen, M.; Persson, Y.; Kanyima, B. M. and Bage, R. (2014): Prevalence of subclinical mastitis in dairy farms in urban and peri-urban areas of Kampala, Uganda. Tropical animal health and production., 46(1), 99-105

Alemu, S.; Tamiru, F.; Almaw, G. and Tsega, A. (2013): Study on bovine mastitis and its effect on chemical composition of milk in and around Gondar Town, Ethiopia. Journal of Veterinary Medicine and Animal Health., 5(8): 215-221.

Allore, H. G. (1993): A review of the incidence of mastitis in buffaloes and cattle. Pakistan Vet. J., 13: 1-7.

Andrei, S.; Adela, P.; Andrea, B.; Groza, I.; Bogdan, L.; Sorana, M.; Simona, C. and Diana, C. (2009): A Bulletin Uasvm. Veterinary Medicine., 66 (1): 196 202.

Awandkar, S. P.; Khode, N. V.; Sardar, V. M. and Mendhe, M. S. (2009): Prevalence and current antibiogram trend of mastitic agents in Udgir and its visinity, Maharashtra State, India. International Journal of Dairy Science., 4(3): 117-122.

Bhattacharya, A. (2002): Etiology and antibiotic spectra of bacterial isolates fro m field cases of mastitis in cases from west Tripura district. Ind. Vet. J., 79: 9 61- 962. 
Biffa, D.; Debela, E. and Beyene, F. (2005): Prevalence and risk factors of mastitis in lactating dairy cows in Southern Ethiopia. Int. J. Appl. Res. Vet. Med. 3(3): 189-198

Bilal, M. Q. and Ahmed, A. (2004): Dairy Hygiene and Disease Prevention. Usman and Bilal Printing Linkers, Faisalabad, Pakistan.

Bitew, M.; Tafere, A. and Tolosa, T. (2010): Study on Bovine Mastitis in Dairy Farms of Bahir Dar and its Environs, Journal of Animal and Veterinary Advances., 9 (23): 2912-2917.

Bytyqi, H.; Zaugg, U.; Sherifi, K.; Hamidi, A.; Gjonbalaj, M.; Muji, .S. and Mehmeti, H. (2010): Influence of management and physiological factors on somatic cell count in raw milk in Kosova. Veterinarski Archiv., 80(2):173-183.

Collee, J.G.; Duggid, J.P.; Fraser, A.G. and Marmion, B.P. (1989): "Practical medical microbiology". 13th.Ed., reprint international student edition. Churchill livingstone and Edinburgh London and New York.

Dalia, M. A. A. H. (2015): Studies on Staphylococcus aureus which causing subclinical mastitis in Raw milk. M.V.SC., Thesis, Milk hygiene, Faculty of Vet. Med., Zagazig Univ.

Denamiel, G., Llorente, P., Carabella, M., Rebuelto, M. and Gentilini, E. (2005): Antimicrobial susceptibility of Streptococcus spp. isolated from bo vinemastitis in Argentina. J. Vet. Med. B. Infect. Dis. Pub. Hlth., 52 (3): 125 $-128$.

El- Zubeir E. M. I.; El- Owni, O. A. O. and Mohamed, G. E. (2005): Correlation of minerals and enzymes in blood serum and milk of healthy and mastitic cows. Journal of Agricultural and Biological Science., 1(1): 45-49.

Elbably, M.A.; Emeash, H.H. and Asmaa. N.M. (2013): Risk factors associated with mastitis occurrence in dairy herds in Beni-Suef Governorate. World's Vet. J., 3(1): 5-10.

Girma, D. D. (2010): Study on prevalence of mastitis on cross Breed Dairy cows Around Holeta areas, West Shewa Zone of Ethiopia. Glob. Vet., 5(6): 318323

Hamdy, A.B.A.H. (2009): Assessment of Apparently Normal Milk through Field and Laboratory Examination. Ph.D. Thesis, Milk hygiene, Faculty of Vet. Med. Alexandria Univ.

Hameed, K. G. A.; Sender, G. and Korwin-Kossakowska, A. (2006): Public health hazard due to mastitis in dairy cows. Animal Science Papers and Reports., 25(2): 73-85.

Hanan, M. E.H.; Sahar, A. G.; Hamouda, R.H. and Dohreig R.M.A. (2015): Immunological and Bacteriological Findings Associated with Subclinical Mastitis in Dairy Farm. Life Science Journal.,12(2): 139-146.

Idriss, E.S.; Foltys, V.; Tancin, V. and Kirchnerova (2014): Antimicrobial agents in dairy cows in Nitra, Slovakia. Slovak J. Anim. Sci., 47, 2014 (1): 33-38.

International Dairy Federation (IDF) (1971): A monograph of bovine mastitis.

Jones, G. M. and Swisher, J. M. (1998): Environmental Streptococcal and Coliform mastitis. Virginia Cooperative Extension, Knowledge for the Common Wealth, Publication Number 505-516, April.

Joshi, S. and Gokhale, S. (2004): Status of mastitis as an emerging disease in improved and periurban dairy farms in India. 23rd World Buiatrics Congress Quebec city, Canada.

Kumar, P.; Sharma, A.; Sindhu, N. and Deora, A. (2014): Acute phase proteins as indicators of inflammation in streptococcal and staphylococcal mastitis in buffaloes. Haryana Veterinarian., 53(1): 46-49.

Leitner, G.; Merin, U. and Silanikove, N. (2011): Effects of glandular bacterial infection and stage of lactation on milk clotting parameters: Comparison among cows, goats and sheep. International Dairy Journal., 21(4): 279285.

Matei, S. T.; Groza, I.; Andrei. S.; Bogdan, L. and Ciupe, S. P. (2010): Serum metabolic parameters in healthy and subclinical mastitiscows. A Bulletin UASVM, Veterinary Medicine., 67(1): 110-114.

Mekibib, B.; Furgasa, M.; Abunna, F.; Megersa, B. and Regassa, A. (2010): Bovine mastitis: prevalence, risk factors and major pathogens in dairy farms of Holeta town, central Ethiopia. Veterinary World., 3(9): 397-403.

Mekonnen, H. and Tesfaye, A. (2010): Prevalence and etiology of mastitis and related management factors in market oriented smallholder dairy farms in Adama, Ethiopia. Revue Med. Vet., 161(12): 574-579.
Mir, A. Q., Bansal, B. K. and Gupta, D. K. (2014): Subclinical mastitis in machine milked dairy farms in Punjab: prevalence, distribution of bacteria and current antibiogram. Veterinary World ., 7(5) : 291-294.

National Mastitis council, (1999): Current concepts of bovine mastitis, 4th ed. Madison, WI.

Owen, J. B.; Axford, R. F. E. and Bishop, S. C. (2000): Mastitis in dairy cattle. Breeding for Disease Resistance in Farm Animals. (Eds) Axford R F E, Bishop S C, Nicholas F W and Owen J.B. CAB International.

Quinn, P.J.; Markey, B.K.; Carter, M.E; Donnelly, W.J.C. and Leonard, F.C. (2002): Veterinary Microbiology and microbial Diseases Blackwell Scientific Publications, Oxford, London.

Quinn, P. J.; Carter, M.E.; Morkey, B. K. and Carter, G. R. (1994): Clinical Vet. Microbiol., 1st ed Mosby-Year book, Wolf Publishing. Spain, London.

Radostits, O.M.; Gay, C.C.; Blood, D.C. and Hinchcliff, K.W. (2000): Veterinary Medicine, A textbook of the disease of cattle, horse, sheep, pigs and goats. 9th ed., Saunders, London, 603-700.

Radostits, O.M.; Gay, C.C.; Hinchcliff, W.K. and Constable, P.D. (2007) Veterinary Medicine, A textbook of the disease of cattle, horse, sheep, pigs and goats. Saunders pub. Tenth edition, 314-325.

Robertson, J. R., Fox, L. K.; Hancock, D. D.; Gay, J. M. and Basser, T. B. (1994): Etiology of Staph. aureus isolated from various sites on dairy farms. J. Dairy Sci. 77: 3354-3364.

Schalm, O.W. and Noorlander, D.O. (1957): Experiments and observations leading to development of the California mastitis test. J. Am. Vet. Med. Assoc. 130 (5): 199-204.

Sharif, A.; Umer, M. and Muhammad, G. (2009): Mastitis control in dairy production. Journal of Agriculture and Social Science., 5(3): 102-105.

Shereen, S.I. (2014): A test of a model based on measurement of C-reactive protein (CRP) and other parameters in milk and blood. A novel principle to estimate individual cow mastitis risk degree. Ph D. Thesis, microbiology, Fac. Vet. Med., Cairo Univ

Singh, K.; Chandra, M.; Kaur, G.; Narang, D. and Gupta. K. (2018): Prevalence and Antibiotic Resistance Pattern among the Mastitis Causing, Microorganisms. Journal of Veterinary Medicine, 2018, 8, 54-64.

Suriyasathaporn, W. (2011): Epidemiology of subclinical mastitis and their antibacterial susceptibility in smallholder dairy farms, Chiang Mai Province ,. Journal of Animal and Veterinary Advances 10 (3): 316-321.

Viguier, C.; Arora, S.; Gilmartin, N.; Welbeck, K. and O’kennedy, R. (2009): Mastitis detection. current trends and future perspectives. Trend. Biotechnol., 27(8): 486-493.

Zaki, M.S.; Sharaf, N.E.; Mostafa, S.O.; Fawzi, O.M. and Batrawy, N.E.L. (2008): Effect of subclinical mastitis on some biochemical and clinicopathological parameters in Buffalo. Am.Eur. J. Agric. Environ. Sci., 3(2): 200-204.

Zecconi, A.; Casirani, G.; Binda, E. and Piccinini, R. (2002): The importance of assess the effects ofvoluntary milking system on teat tissues, intramammary infections and somatic cell counts, Dept. In Anim. Path.-Infect. Dis. Lab., University of Mailan, Delaval Hygiene, Technology center, Inaugal Symposium.

Zeinhom, M.M.A; Abed, A.H. and Hashem, k.S. (2013): A contribution towards milk enzymes, somatic cell count and bacterial pathogens associated with subclinical mastitis cows milk. Assiut Vet. Med. J., 59 (138): 38-48.

Zenebe, N.; Habtamu, T. and Endale, B. (2014): Study on bovine mastitis and associated risk factors in Adigrat, Northern Ethiopia. African Journal of Microbiology Research., 8 (4): 327-331.

Zeryehun, T.; Aya, T. and Bayecha, R. (2013): Study on prevalence, bacteria pathogens and associated risk factors of bovine mastitis in small holder dairy farms in and around AddisAbaba, Ethiopia., 23(1): 50-55.

Zizet, Z.Z. (2015): Evaluation of different methods used for diagnosis of bovine subclinical mastitis and determination of the udder immune response against it. Ph.D. Vet. Sc. Faculty of Vet. Med. Cairo Univ. 